\title{
Synthesis and Anion Binding Properties of a Novel 1,8-dipyrrolecarbazole Schiff-base
}

\author{
Marina Šekutor, Saša Opačak, Marija Alešković, Kata Mlinarić-Majerski*
}

\author{
Department of Organic Chemistry and Biochemistry, Ruđer Bošković Institute, Bijenička cesta 54, P.O. Box 180, 10 002, Zagreb, Croatia \\ * Corresponding author's e-mail address: majerski@irb.hr
}

RECEIVED: October 15, 2015 * REVISED: October 28, 2015 * ACCEPTED: October 28, 2015

THIS PAPER IS DEDICATED TO DR. SVETOZAR MUSiĆ ON THE OCCASION OF HIS 70 Th BIRTHDAY

\begin{abstract}
New anion receptor $N^{1}, N^{8}$-bis[1 $1 \mathrm{H}$-pyrro-2-yl-methylidene]-3,6-dichloro-9H-carbazole-1,8-diamine (3) was synthesized and its binding properties towards anions $\left(\mathrm{Cl}^{-}, \mathrm{Br}^{-}, \mathrm{AcO}^{-}\right.$and $\left.\mathrm{H}_{2} \mathrm{PO}_{4}^{-}\right)$investigated by UV/Vis spectroscopy. In order to find the most stable structure of receptor 3 , geometries of all possible isomers of $\mathbf{3}$ were optimized by the DFT/B3LYP method. It has been determined that receptor $\mathbf{3}$ forms complexes with a 1:1 stoichiometry with all the studied anions and no significant selectivity with respect to anion geometry was found. However, 1,8dipyrrolecarbazole Schiff-base 3 binds oxoanions $\left(\mathrm{H}_{2} \mathrm{PO}_{4}^{-}\right.$and $\left.\mathrm{AcO}^{-}\right)$more strongly than spherical halogenide $\left(\mathrm{Cl}^{-}\right.$and $\left.\mathrm{Br}^{-}\right)$anions.
\end{abstract}

Keywords: anion receptors, carbazole, pyrrole, Schiff-base.

\section{INTRODUCTION}

$\mathbf{T}$ HE development of selective anion receptors ${ }^{[1]}$ for different applications ${ }^{[2]}$ has been driven by the key roles that anions play in chemical and biological processes. Over the past few decades a considerable interest has been focused to produce a variety of new anion receptors based on the $\mathrm{H}$-bonding interactions. A large number of molecules which are used as anion receptors are composed of amide, urea, thiourea, pyrrole, indole and similar $\mathrm{H}$-bonding donors. ${ }^{[3]}$ For example, pyrroles have the acidic NH hydrogen to which anions can bind by forming a hydrogen bond. Anion binding has been reported for the derivatives of amidopyrroles, ${ }^{[4]}$ calixpyrrole, ${ }^{[5]}$ porphyrines, ${ }^{[6]}$ as well as dipyrromethanes. ${ }^{[7]}$

After Jurczak et al. ${ }^{[8]}$ showed that the rigid $\pi$-conjugated skeleton of carbazole allows an easy introduction of various functionalities, the carbazole molecule became an ideal moiety for the design of efficient anion receptors. ${ }^{[9]}$ Carbazole also has the polarized NH hydrogen which can form the $\mathrm{H}$-bond with anions. Additionally, carbazole derivatives are often colored which enables their spectrophotometric detection. ${ }^{[10]}$ Many anion receptors containing the carbazole backbone have been prepared, ${ }^{[8,11]}$ some of them also in combination with the pyrrole moiety. ${ }^{[9,12]}$

On the other hand, the examples of carbazole Schiff-base anion receptors are very rare in the literature. ${ }^{[13]}$ Although various anion receptors containing a carbazole or a pyrrole are known, to the best of our knowledge, the receptor which is composed of those structural subunits combined in a single molecule and attached to each other by the imine nitrogen has not been reported yet. The incorporation of the rigid imine double bond would lead to a more rigid receptor which could participate in hydrogen bonding with its two pyrrole moieties, thus improving the receptor binding and/or selectivity towards anions.

Herein, we report the synthesis of hitherto unknown 1,8-dipyrrolecarbazole Schiff-base 3 and its binding abilities towards anions $\left(\mathrm{Cl}^{-}, \mathrm{Br}^{-}, \mathrm{AcO}^{-}\right.$and $\left.\mathrm{H}_{2} \mathrm{PO}_{4}^{-}\right)$.

\section{EXPERIMENTAL}

${ }^{1} \mathrm{H}$ and ${ }^{13} \mathrm{C}$ NMR spectra were recorded on a Bruker AV-300 Spectrometer at $300 \mathrm{MHz}$. The NMR spectra were measured in DMSO- $d_{6}$ using tetramethylsilane as a reference. IR spectra were recorded on a FT-IR ABB Bomem MB 102 

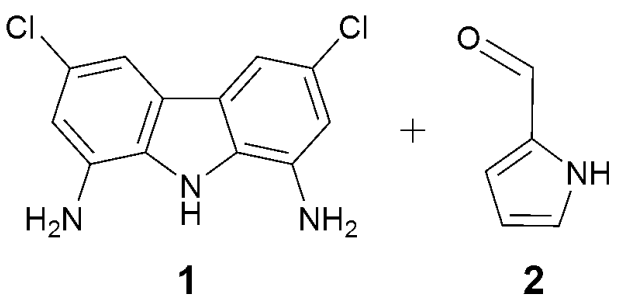
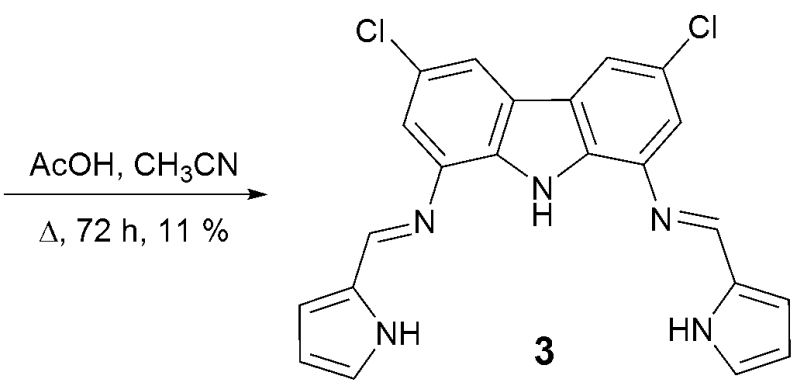

Scheme 1. Synthesis of receptor 3.

spectrophotometer. Melting points were determined using an Original Kofler Mikroheitztisch apparatus (Reichert, Wien) and are uncorrected. The starting 1,8-diamino-3,6dichlorocarbazole (1) was prepared according to the previously published procedure. ${ }^{[8]}$

$\mathrm{N}^{1}, \mathrm{~N}^{8}$-bis[1H-pyrro-2-yl-methylidene]-3,6-dichloro-9Hcarbazole-1,8-diamine (3): To 1,8-diamino-3,6-dichlorocarbazole (1) $(233 \mathrm{mg}, 0.9 \mathrm{mmol}$ ) and pyrrole-2-carboxaldehyde (2) $(416 \mathrm{mg}, 4.4 \mathrm{mmol}$ ) dissolved in acetonitrile (40 $\mathrm{mL}$ ) a few drops of glacial acetic acid was added and the reaction mixture was refluxed for $72 \mathrm{~h}$. After the carbazole derivative was fully consumed (monitored by $\mathrm{TLC}, \mathrm{CH}_{2} \mathrm{Cl}_{2}$ as eluent), the reaction mixture was cooled to room temperature and the solvent evaporated. The crude product was purified by column chromatography $\left(\mathrm{Al}_{2} \mathrm{O}_{3}\right.$, activity 5 , $\mathrm{CH}_{2} \mathrm{Cl}_{2}$ as eluent) yielding the pure title compound as a yellow solid, $42 \mathrm{mg}$ (11\%); m.p. decomposition over $300^{\circ} \mathrm{C}$; $\mathrm{UV}\left(\mathrm{CH}_{3} \mathrm{CN}\right) \lambda_{\max } / \mathrm{nm}$ : 316 and $384\left(\log \varepsilon / \mathrm{dm}^{3} \mathrm{~mol}^{-1} \mathrm{~cm}^{-1}\right.$ : 4.09 and 3.86); IR(KBr) $\tilde{v}_{\max } / \mathrm{cm}^{-1}: 3425(\mathrm{w}), 1612(\mathrm{~s}), 1570$ (m), $1417(\mathrm{~s}), 1337(\mathrm{~m}), 1088(\mathrm{w}), 1031(\mathrm{~s}), 742(\mathrm{~m}) ;{ }^{1} \mathrm{H}$ NMR (DMSO- $d_{6}, 300 \mathrm{MHz}$ ) $\delta$ / ppm: 6.25-6.30 (m, 2H), 6.78-6.83 $(\mathrm{m}, 2 \mathrm{H}), 7.20(\mathrm{~s}, 2 \mathrm{H}), 7.35(\mathrm{~d}, J=1.8 \mathrm{~Hz}, 2 \mathrm{H}), 8.08(\mathrm{~d}, J=1.8$ $\mathrm{Hz}, 2 \mathrm{H}), 8.67(\mathrm{~s}, 2 \mathrm{H}), 10.74(\mathrm{~s}, \mathrm{NH}, 1 \mathrm{H}), 11.76(\mathrm{~s}, \mathrm{NH}, 2 \mathrm{H}) ;{ }^{13} \mathrm{C}$ NMR (DMSO- $\left.d_{6}, 75 \mathrm{MHz}\right) \delta / \mathrm{ppm}: 150.2(\mathrm{CH}, 2 \mathrm{C}), 137.0$ (C, 2C), $134.4(\mathrm{C}, 2 \mathrm{C}), 131.1(\mathrm{C}, 2 \mathrm{C}), 124.2(\mathrm{CH}, 2 \mathrm{C}), 124.1(\mathrm{C}$, 2C), $123.6(\mathrm{C}, 2 \mathrm{C}), 116.8(\mathrm{CH}, 2 \mathrm{C}), 116.6(\mathrm{CH}, 2 \mathrm{C}), 113.1(\mathrm{CH}$, 2C), $110.1(\mathrm{CH}, 2 \mathrm{C})$.

\section{Titration Experiments}

The UV/Vis titration experiments were performed on a PG instruments limited T80+ spectrophotometer at $25^{\circ} \mathrm{C}$. The receptor was dissolved in spectroscopic grade $\mathrm{CH}_{3} \mathrm{CN}(c=$ $5.5 \times 10^{-5} \mathrm{~mol} \mathrm{dm}^{-3}$ ), the concentration corresponding to the maximum of absorbance in the range $0.6-0.9$. The solution of the receptor was placed in a quartz cuvette $(I=1 \mathrm{~cm}$, $V=0.9 \mathrm{~mL}$ ), UV/Vis spectrum was recorded and then aliquots of the corresponding anion were added. Solutions of tetrabutylammonium salts of the anions were used ( $\mathrm{TBAH}_{2} \mathrm{PO}_{4}, \mathrm{TBAOAC}, \mathrm{TBACl}$, and TBABr), with the concentration range $10^{-4}-10^{-1} \mathrm{~mol} \mathrm{dm}^{-3}$. UV/Vis spectra were recorded after each addition and the obtained spectrometric data was processed using the Specfit program. ${ }^{[14]}$

\section{Calculations}

All calculations were performed using the Gaussian 03 software package. ${ }^{[15]}$ Isomers were first optimized with the semiempirical PM3 method ${ }^{[16]}$ and final geometrical optimization of the structures and verification of the minima were done at the B3LYP/6-31G level of theory. ${ }^{[17]}$ Enthalpies were obtained by correcting electronic energies for unscaled zero-point vibrational energy and work term $\left(E_{\mathrm{w}}=\right.$ $R T$ ) as implemented in Gaussian 03. All energies are given in $\mathrm{kcal} \mathrm{mol}^{-1}\left(1 \mathrm{kcal} \mathrm{mol}^{-1}=4.184 \mathrm{~kJ} \mathrm{~mol}^{-1}\right)$.

\section{RESULTS AND DISCUSSION}

Since the main goal of this study was to combine the carbazole, pyrrole and Schiff base subunit in a single molecule in order to evaluate its anion binding properties, the key precursor for the synthesis of receptor 3 was 1,8-diamino-3,6dichlorocarbazole (1). ${ }^{[8]}$ The preparation included selective chlorination of the carbazole hydrocarbon in positions 3 and 6 (the most reactive positions of the molecule) followed by nitration in positions 1 and 8 of the carbazole framework. The obtained nitro-derivative was reduced in the atmosphere of hydrogen with $10 \% \mathrm{Pd} / \mathrm{C}$ as a catalyst, yielding the carbazole amine 1 . Its subsequent condensation with pyrrole-2-carboxaldehyde (2) finally gave rise to the desired receptor $\mathbf{3}$ (Scheme 1).

Although the condensation reaction to obtain $\mathbf{3}$ is a classical nucleophilic carbonyl addition, the reaction proceeded very slowly and took three days to reach completion. We hypothesize that the reason for such low reactivity is a deactivation of the aminocarbazole due to the presence of the chloro-substituents in the aromatic ring, making the amine a weak nucleophile. Nevertheless, the conversion of aminocarbazole 1 to receptor 3 was quantitative after $72 \mathrm{~h}$ (confirmed by the NMR spectra of the crude reaction mixture). Regardless of the several crystallizations the purity of $\mathbf{3}$ was unsatisfactory for the titration experiments. Therefore, aware of the inherent imine instability, we resorted to mild 

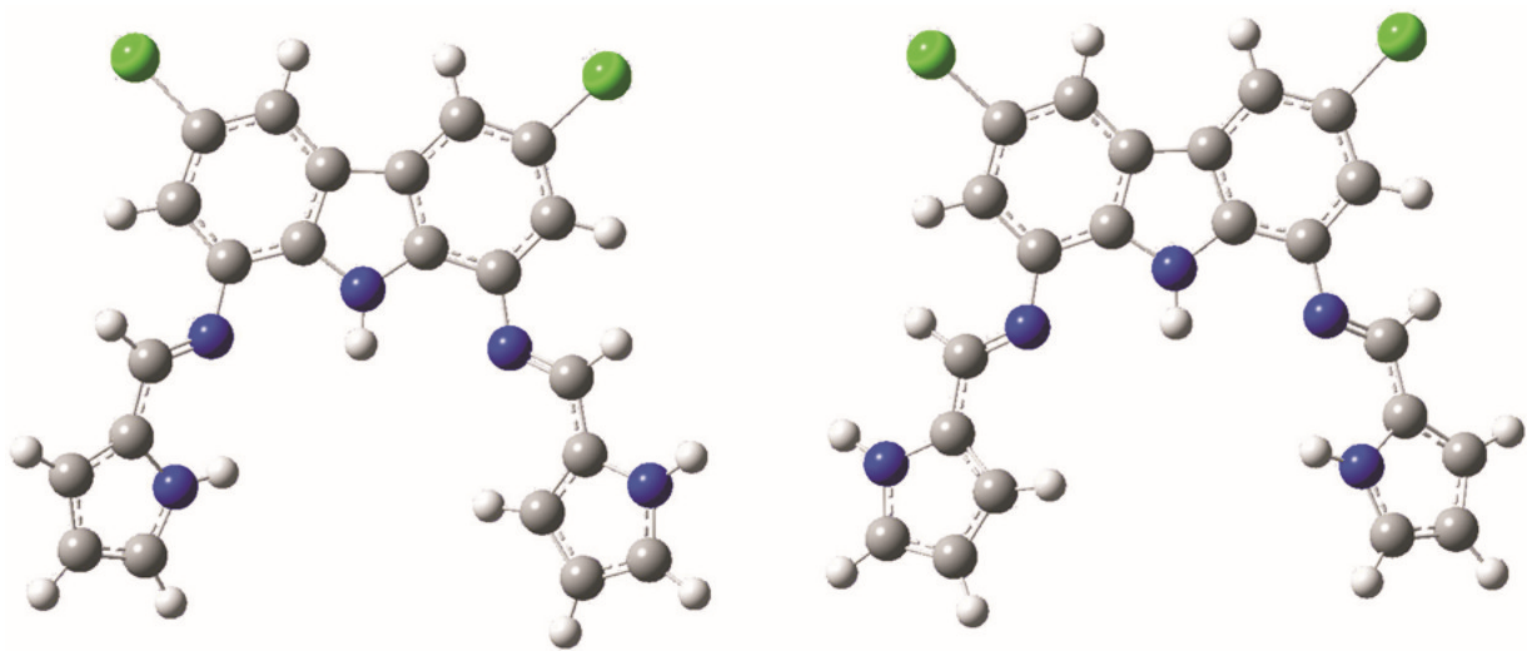

Figure 1. Symmetrically equivalent stereoisomers of compound 3; isomers $E$-out-in-E-out-out (left) and $E$-out-out- $E$-out-in (right) have the same geometry.

chromatography conditions, and we succeed to obtain the analytically pure receptor $\mathbf{3}$ in $11 \%$ of yield.

To the best of our knowledge, compound $\mathbf{3}$ is the first example of a 1,8- $N$-substituted carbazole Schiff base combined with the pyrrole subunits. The pyrrole moiety was used because the resulting central cavity was deemed ideal for realizing multiple binding interactions between the receptor heteroatoms and the anions. The dimensions of the cavity are perfectly suited for anion coordination by means of hydrogen bond formation. For that purpose the NH groups of the carbazole and the pyrroles as well as the electron pairs on the imine nitrogens are utilized. Additional advantage of receptor $\mathbf{3}$ is the possibility of conjugation throughout the whole molecule which causes changes in the absorption spectra during anion binding. The compound can therefore be applied as a receptor by using the UV/Vis titration method.

Compound $\mathbf{3}$ can in theory exist in many stereoisomeric forms due to the possible isomerization around the imine double bond as well as to the rotation of two pyrrole rings. However, the NMR spectra clearly show that only one isomer is formed when applying the described reaction conditions. In order to gain insight into the exact geometry of receptor 3, quantum mechanical calculations of conformationally relevant structures were performed. The isomer structures were first optimized using the semiempirical PM3 method and the obtained geometries were then recalculated at the B3LYP/6-31G level of theory. The calculations were performed only for the isomers having the $E$ configuration of the double imine bond since we found that the $Z$ isomers undergo a severe twist resulting in the significant loss of molecular planarity. In order to easily distinguish between different stereoisomers, the combination of $E$ and in/out designations is used to produce a ",E-in/outin/out- $E$-in/out-in/out" system. Namely, the first $E$ describes the configuration of the imine double bond on position 1 of the carbazole ring, the first in/out describes the orientation of the double bond with respect to the center of the molecule (to the carbazole $\mathrm{NH}$ ) and the second in/out describes the orientation of the pyrrole $\mathrm{NH}$, also with respect to the molecule center. The second half of the designation analogously describes the orientation of groups present on position 8 of the carbazole framework. However, only ten $E$ isomer geometries are relevant even though sixteen $E$ structures can be constructed. This reduction in stereoisomer diversity is due to symmetry reasons and can be revealed by a simple $180^{\circ}$ rotation around the axis bisecting the central plane of the carbazole skeleton (Figure 1).

Table 1 summarizes the calculation results obtained for the ten relevant $E$ stereoisomers of compound 3 . The energy minimum for $\mathbf{3}$ a could not be achieved as the starting geometry was always converted to that of another isomer during the calculation. This observation points toward a probable instability of the structure and is reasonable to expect since the central cavity probably experiences a severe strain. The data for all the calculated stereoisomers show that both levels of theory give comparable relations between the relative energies, adding to the reliability of using these methods for the studied molecule type.

According to the theoretical study, the most stable stereoisomer of receptor $\mathbf{3}$ is the $E$-out-in- $E$-out-in isomer $3 c$ (Figure 2). In this structure both imine double bonds are oriented away from the cavity center, thereby exposing the lone electron pair on nitrogen to the inside of the cavity. Furthermore, both pyrrole hydrogens in $\mathbf{3 c}$ are oriented towards the center of the molecule and the cavity therefore has a potential to effectively stabilize the anions. The energetically most stable geometry of $\mathbf{3}$ is at the same time the most suitable structure for successful anion binding. 
Table 1. Calculated energies and enthalpies for stereoisomers of 3

\begin{tabular}{|c|c|c|c|}
\hline Compound & Isomer & $\begin{array}{c}\mathrm{PM} 3 \\
E_{\mathrm{rel}} \\
\end{array}$ & $\begin{array}{c}\text { B3LYP/6-31G } \\
H_{\text {rel }} \\
\end{array}$ \\
\hline $3 a$ & $E$-in-in-E-in-in & - & - \\
\hline $3 b$ & $E$-in-out- $E$-in-out & 4.9 & 7.0 \\
\hline $3 c$ & $E$-out-in-E-out-in & 0 & 0 \\
\hline $3 d$ & $E$-out-out-E-out-out & 5.5 & 7.0 \\
\hline $3 e$ & $E$-in-in- $E$-in-out & 8.5 & 11.8 \\
\hline $3 f$ & $E$-in-in- $E$-out-in & 6.2 & 7.6 \\
\hline $3 g$ & $E$-in-in-E-out-out & 8.4 & 11.2 \\
\hline $3 h$ & $E$-in-out- $E$-out-in & 2.4 & 3.6 \\
\hline $3 i$ & $E$-in-out-E-out-out & 5.1 & 6.6 \\
\hline $3 j$ & $E$-out-in-E-out-out & 2.5 & 3.3 \\
\hline
\end{tabular}

In case of isomers $\mathbf{3 e}$ and $\mathbf{3 g}$ the repulsions inside the cavity are obviously very high and these isomers, along with 3a, are the least stable geometries of receptor $\mathbf{3}$.

After ascertaining the most stable geometry of receptor 3, we next proceeded with evaluation of its anion binding abilities. For that purpose we used $\mathrm{H}_{2} \mathrm{PO}_{4}^{-}, \mathrm{AcO}^{-}, \mathrm{Cl}^{-}$ and $\mathrm{Br}^{-}$anions. Since receptor 3 has a fully conjugated structure and absorbs light in the UV/Vis region, the spectrophotometric titration was the preferred method to study the binding. The central cavity of the receptor undergoes changes during the approach and subsequent binding of the anion, resulting in differences in the absorption spectra and enabling the stability constant calculation. The obtained results are presented in Figure 3 and Table 2.

Titration of receptor 3 with selected anions resulted in noticeable spectral changes (Figure 3). Isosbestic points could be determined for all the studied complexes, pointing toward an equilibrium between two colored species. The isosbestic point for $\mathrm{H}_{2} \mathrm{PO}_{4}^{-}$was present at $313 \mathrm{~nm}$, for $\mathrm{AcO}^{-}$ at $310 \mathrm{~nm}$, for $\mathrm{Cl}^{-}$at 280,314, 351, and $380 \mathrm{~nm}$ and for $\mathrm{Br}^{-}$ at 413 and $336 \mathrm{~nm}$. Additionally, a bathochromic shift in the spectra was observed during the titration and is a consequence of complex formation. The reason for the observed red shift phenomenon is the change of electron density in the receptor during anion binding. To gain insight into the electron density distribution, we calculated the corresponding molecular orbitals (HOMO and LUMO) of receptor 3. The results show that in case of HOMO the highest electron density is located on the carbazole ring and to some extent on the pyrrole rings (Figure 4). On the other hand, the highest LUMO density is noticeably prevalent on the imine and pyrrole substructures, indicating that the electron transition of the LUMO accounts for the bathochromic

Table 2. Stability constants for complexes of 3 with different anions determined by UV/Vis titrations(a)

\begin{tabular}{ccccc}
\hline Anion & $\mathrm{H}_{2} \mathrm{PO}_{4}^{-}$ & $\mathrm{AcO}^{-}$ & $\mathrm{Cl}^{-}$ & $\mathrm{Br}^{-}$ \\
\hline $\log \theta \pm \sigma(\log \theta)$ & $4.79 \pm 0.07$ & $4.35 \pm 0.05$ & $3.41 \pm 0.03$ & $3.50 \pm 0.07$ \\
\hline (a)
\end{tabular}

(a) Titrations were conducted in acetonitrile at $25^{\circ} \mathrm{C}$, the starting concentration of 3 was $c=5.5 \times 10^{-5} \mathrm{~mol} \mathrm{dm}^{-3}$, anions were added as TBA salts, the spectra were corrected for dilution, the best fits were obtained for a 1:1 receptor-anion model.
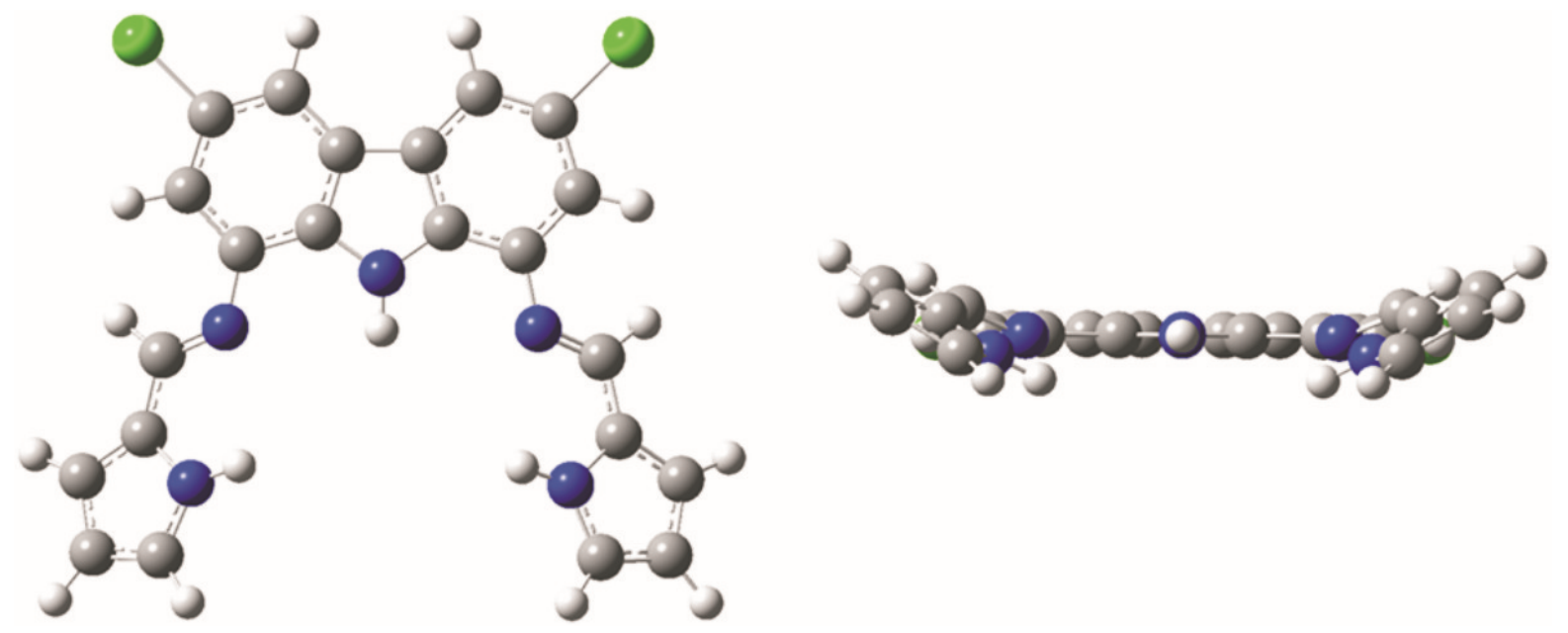

Figure 2. Optimized geometry of 3c; view from two sides. 
(a)

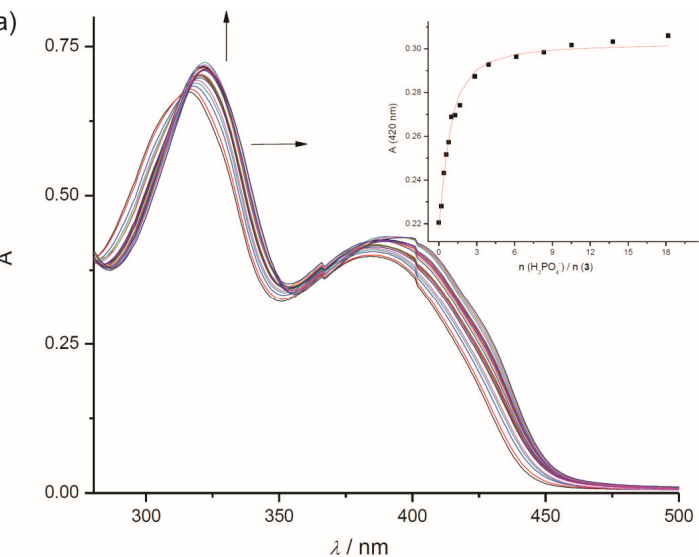

(c)

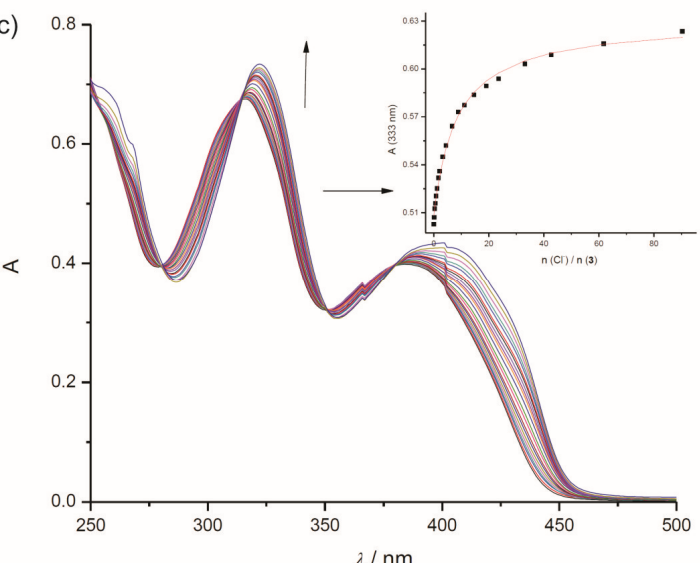

(b)

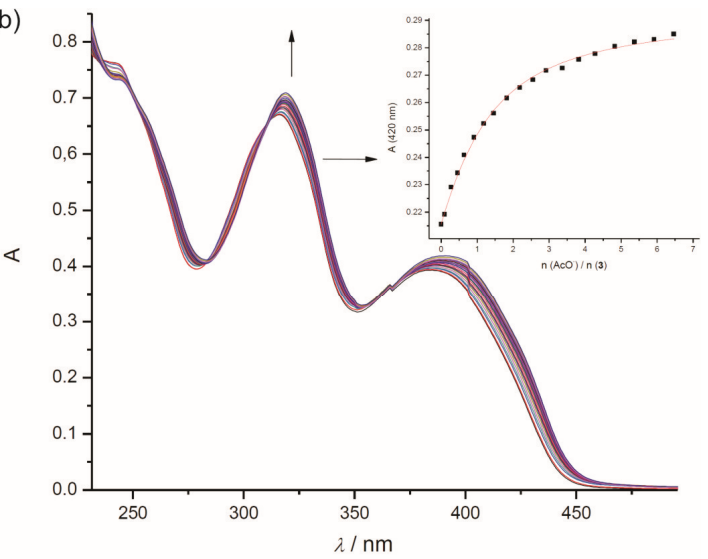

(d)

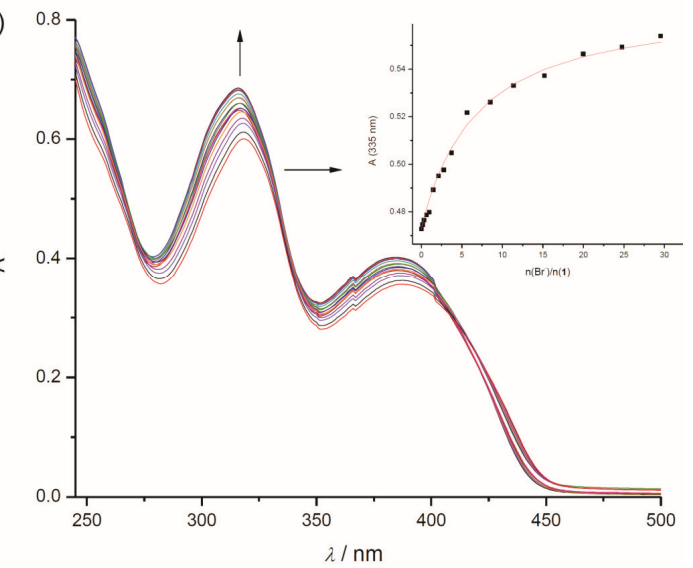

Figure 3. UV/Vis titrations of receptor $3\left(c=5.5 \times 10^{-5} \mathrm{~mol} \mathrm{dm}^{-3}\right.$ ) with $\mathrm{H}_{2} \mathrm{PO}_{4}^{-}$(a), $\mathrm{AcO}^{-}$(b), $\mathrm{Cl}^{-}$(c), and $\mathrm{Br}^{-}$(d) in $\mathrm{CH}_{3} \mathrm{CN}^{-}$at $25{ }^{\circ} \mathrm{C}$. Insets: absorbance of the $\mathrm{CH}_{3} \mathrm{CN}$ solution of 3 versus mole ration of anion/3 (- exp. values, — calcd. values).
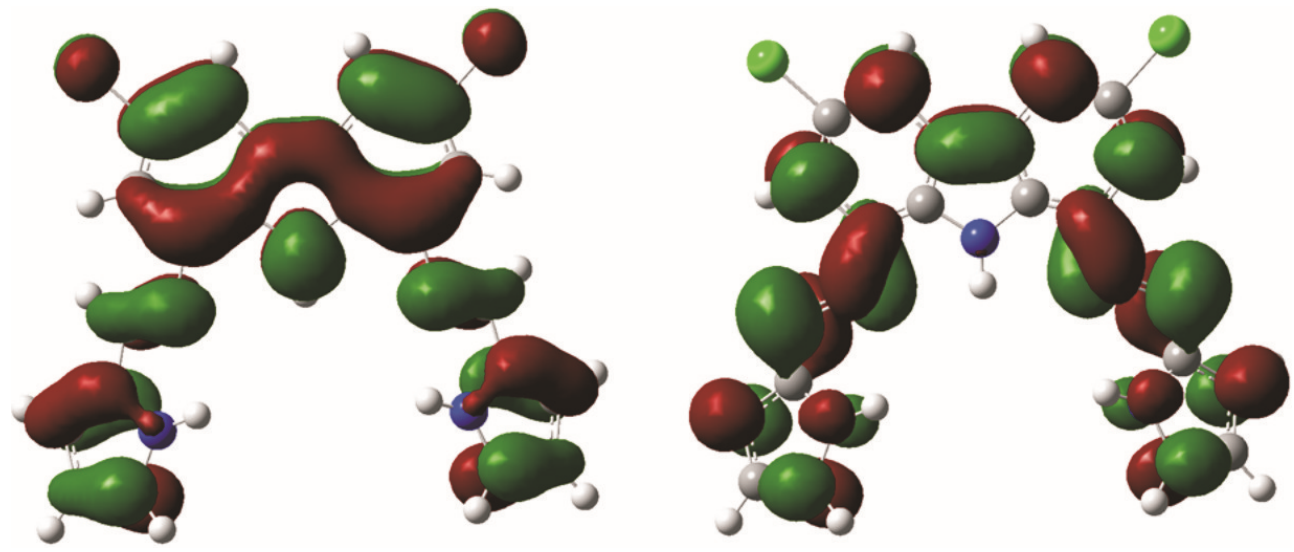

Figure 4. Calculated isodensity surfaces of HOMO (left) and LUMO (right) orbitals of receptor 3.

shift observed in the absorption spectra of the complexes. In other words, the anion binding processes stabilize the LUMO somewhat and cause the red shift in the UV/Vis spectra.
From the spectral data we could determine that receptor $\mathbf{3}$ forms the most stable complexes with a 1:1 receptor-anion stoichiometry for all the studied anions. The 
corresponding stability constants (Table 2) were calculated using the Specfit program. ${ }^{[14]}$ The highest value of the stability constant was determined for $\mathrm{H}_{2} \mathrm{PO}_{4}^{-}$, followed closely by $\mathrm{AcO}^{-}$. Although no marked difference in selectivity was obtained, we found that the receptor 3 binds oxoanions $\left(\mathrm{H}_{2} \mathrm{PO}_{4}^{-}\right.$and $\left.\mathrm{AcO}^{-}\right)$better than spherical haloanions $\left(\mathrm{Cl}^{-}\right.$and $\left.\mathrm{Br}^{-}\right)$. The observed preference can be correlated with anion basicity since $\mathrm{AcO}^{-}$and $\mathrm{H}_{2} \mathrm{PO}_{4}{ }^{-}$are more basic than the halogen anions. However, here should be noted that $\mathrm{H}_{2} \mathrm{PO}_{4}^{-}$binds stronger to the receptor than the more basic $\mathrm{AcO}^{-}$. Since it is known that multiple bonding interactions are important for the formation of strong complexes, the participation of the dihydrogenfosfate $\mathrm{OH}$ group in the binding process and its possible interaction with the imine nitrogen probably has a beneficial overall effect on the binding.

\section{CONCLUSION}

In conclusion, we prepared a novel 1,8-dipyrrolecarbazole Schiff-base $\mathbf{3}$ and determined its most stable geometry using theoretical methods. We also studied the binding properties of receptor 3 towards anions $\left(\mathrm{Cl}^{-}, \mathrm{Br}^{-}, \mathrm{AcO}^{-}\right.$and $\left.\mathrm{H}_{2} \mathrm{PO}_{4}^{-}\right)$by UV/Vis spectroscopy. It was demonstrated that receptor 3 forms complexes with a 1:1 stoichiometry with all the studied anions and that it binds oxoanions more strongly than spherical halogenides. The result could be explained in part due to anion basicity but also because the receptor can probably accomplish multiple interactions with the oxoanions inside the central cavity.

Acknowledgment. We thank the Ministry of Science, Education and Sports of the Republic of Croatia for financial support (grant no. 098-0982933-2911).

\section{REFERENCES}

[1] (a) P. A. Gale, N. Busschaert, C. J. Haynes, L. E. Karagiannidis, I. L. Kirby, Chem. Soc. Rev. 2014, 43, 205. (b) M. E. Moragues, R. Martinez-Manez, F. Sancenon, Chem. Soc. Rev. 2011, 40, 2593. (c) F. P. Schmidtchen, Coord. Chem. Rev. 2006, 250, 2918. (d) P. A. Gale, Acc. Chem. Res. 2006, 39, 465. (e) E. A. Katayev, Y. A. Ustynyuk, J. L. Sessler, Coord. Chem. Rev. 2006, 250, 3004. (f) S. O. Kang, A. Begum, K. Bowman-James, Angew. Chem Int. Ed. 2006, 45, 7882. (g) F. P. Schmidtchen, in: I. Stibor (Ed.): Top. Curr. Chem. 255, Springer, Berlin, 2005, pp. 1-29.

[2] (a) M. D. Lankshear, P. D. Beer, Coord. Chem. Rev. 2006, 250, 3142. (b) N. Gimeno, R. Vilar, Coord. Chem. Rev. 2006, 250, 3161. (c) R. Martínez-Máñez, F. Sancenón, Chem. Rev. 2003, 103, 4419. (d) T. Gunnlaugsson, M. Glynn, G. M. Tocci, P. E. Kruger, F.
M. Pfeffer, Coord. Chem. Rev. 2006, 250, 3094. (e) F. Davis, S. D. Collyer, S. P. J. Higson, in: I. Stibor (Ed.): Top. Curr. Chem., 255, Springer, Berlin, 2005, pp. 97124. (f) J. F. Callan, A. P. de Silva, D. C. Magri, Tetrahedron 2005, 61, 8551. (g) P. Buhlmann, E. Pretsch, E. Bakker, Chem. Rev. 1998, 98, 1593. (h) A. P. de Silva, H. Q. N. Gunaratne, T. Gunnlaugsson, A. J. M. Huxley, C. P. McCoy, J. T. Rademacher, T. E. Rice, Chem. Rev. 1997, 97, 1515.

[3] (a) S. O. Kang, K. Begum, R. A. Bowman Bames, Angew. Chem. Int. Ed. 2006, 45, 7882. (b) P. Dydio, D. Lichosyt, J. Jurczak, Chem. Soc. Rev. 2011, 40, 2971. (c) V. Blažek Bregović, N. Basarić, K. MlinarićMajerski, Coord. Chem. Rev. 2015, 295, 80. (d) A. F. Li, J. Wang, F. Wang, Y. B. Jiang, Chem. Soc. Rev. 2010, 39, 3729. (e) V. Amendola, L. Fabbrizzi, L. Mosca, Chem. Soc. Rev. 2010, 39, 3889. (f) C. R. Bondy, S. J. Loeb, Coord. Chem. Rev. 2003, 240, 77.

[4] (a) P. A. Gale, Chem. Commun. 2005, 3761. (b) J. L. Sessler, G. D. Pantos, P. A. Gale, M. E. Light, Org. Lett. 2006, 8, 1593. (c) C.-L. Chen, Y.-H. Chen, Y.-C. Chen, S.-S. Sun, Org. Lett. 2006, 8, 5053.

[5] (a) P. A. Gale, J. L. Sessler, V. Král, Chem. Commun. 1998, 1. (b) P. A. Gale, P. Jr. Anzenbacher, J. L. Sessler, Coord. Chem. Rev. 2001, 222, 57. (c) R. Nishiyabu, P. Jr. Anzenbacher, J. Am. Chem. Soc. 2005, 127, 8270. (d) R. Nishiyabu, M. A. Palacios, W. Dehaen, P. Jr. Anzenbacher, J. Am. Chem. Soc. 2006, 128, 11496. (e) R. Nishiyabu, P. Jr. Anzenbacher, Org. Lett. 2006, 8, 359. (f) J. L. Sessler, D. E. Gross, W. S. Cho, V. M. Lynch, F. P. Schmidtchen, G. W. Bates, M. E. Light, P. A. Gale, J. Am. Chem. Soc. 2006, 128, 12281. (g). M. Alešković, I. Halasz, N. Basarić, K. Mlinarić-Majerski, Tetrahedron 2009, 65, 2051.

[6] (a) J. L. Sessler, N. A. Tvermoes, J. Davis, P. Jr. Anzenbacher, K. Jursíková, W. Sato, D. Seidel, V. Lynch, C. B. Black, A. Try, B. Andrioletti, G. Hemmi, T. D. Mody, D. J. Magda, V. Král, Pure Appl. Chem. 1999, 71, 2009. (b) J. L. Sessler, R. S. Zimmerman, C. Bucher, V. Král, B. Andrioletti, Pure Appl. Chem. 2001, 73, 1041.

[7] (a) J. L. Sessler, H. Maeda, T. Mizuno, V. M. Lynch, H. Furuta, Chem. Commun. 2002, 862. (b) J. L. Sessler, G. D. Pantos, E. Katayev, V. M. Lynch, Org. Lett. 2003, 5, 4141. (c) I. E. D. Vega, S. Camiolo, P. A. Gale, M. B. Hursthouse, M. E. Light, Chem. Commun. 2003, 1686. (d) I. E. D. Vega, P. A. Gale, M. B. Hursthouse, M. E. Light, Org. Biomol. Chem. 2004, 2, 2935. (e) E. A. Katayev, N. V. Boev, V. N. Khrustalev, Y. A. Ustynyuk, I. G. Tananaev, J. L. Sessler, J. Org. Chem. 2007, 72, 2886. (f) J. L. Sessler, E. Katayev, G. D. Pantos, P. Scherbakov, M. D. Reshetova, V. N. Khrustalev, V. M. Lynch, Y. A. Ustynyuk, J. Am. Chem. 
Soc. 2005, 127, 11442. (g) J. L. Sessler, E. Katayev, G. D. Pantosa, Y. A. Ustynyuk, Chem. Commun. 2004, 1276. (h) J. L. Sessler, V. Roznyatovskiy, G. D. Pantos, N. E. Borisova, M. D. Reshetova, V. M. Lynch, V. N. Khrustalev, Y A. Ustynyuk, Org. Lett. 2005, 7, 5277. (i) J. L Sessler, D. An, W.-S. Cho, V. Lynch, M. Marquez, Chem. Eur. J. 2005, 11, 2001. (j) M. Renić, N. Basarić, K. Mlinarić-Majerski, Tetrahedron Lett. 2007, 48, 7873. (k) M. Alešković, N. Basarić, K. Mlinarić-Majerski, K. Molčanov, B. Kojić-Prodić, M. K. Kesharwani, B. Ganguly, Tetrahedron 2010, 66, 1689. (I) M. Alešković, N. Basarić, I. Halasz, X. Liang, W. Qin, K. Mlinarić-Majerski, Tetrahedron 2013, 69, 1725.

[8] M. J. Chmielewski, M. Charon, J. Jurczak, Org. Lett. 2004, 6, 3501.

[9] P. Piatek, V. M. Lynch, J. L. Sessler, J. Am. Chem. Soc. 2004, 126, 16073.

[10] (a) S. M. Bonesi, R. Erra-Balsells, J. Lumin. 2001, 93, 51. (b) A. Labudzinska, S. Galka, K. Gorczynska, J. Mol. Struct. 1993, 294, 247.

[11] (a) K. M. Bak, M. J. Chmielewski, Chem. Commun. 2014, 50, 1305. (b) P. A. Gale, J. R. Hiscock, C. Z. Jie, M. B. Hursthouse, M. E. Light, Chem. Sci. 2010, 1, 215. (c) M. B. Jiménez, V. Alcázar, R. Peláez, F. Sanz, Á. L. Caballero, M. C. Fuentes de Arriba, Org. Biomol. Chem. 2012, 10, 1181. (d) T. D. Thangadurai, N. J. Singh, I. C. Hwang, J. W. Lee, R. P. Chandran, K. S. Kim, J. Org. Chem. 2007, 72, 5461. (e). S. K. Lee, Y. Han, Y. Choi, J. Kang, J. Incl. Phenom. Macrocycl. Chem. 2012, 74, 177. (f) G. Sanchez, A. Espinosa, D. Curiel, A. Tarraga, P. Molina, J. Org. Chem. 2013, 78, 9725. (g) N. Ahmed, I. Geronimo, I. C. Hwang, N. J. Singh, K. S. Kim, Chem. Eur. J. 2011, 17, 8542. (h) J. R. Hiscock, P. A. Gale, C. Caltagirone, M. B. Hursthouse, M. E. Light, Supramol. Chem. 2010, 22, 647. (i) J. R. Hiscock, C. Caltagirone, M. E. Light, M. B. Hursthouse, P. A. Gale, Org. Biomol. Chem. 2009, 7, 1781. (j) N. Ahmed, V. Suresh, B. Shirinfar, I. Geronimo, A. Bist, I. C. Hwang, K. S. Kim, Org. Biomol. Chem. 2012, 10, 2094.
[12] D. E. Gross, V. Mikkilineni, V. M. Lynch, J. L. Sessler, Supramol. Chem. 2010, 22, 135.

[13] (a) X. Shang, X. Li, J. Han, S. Jia, J. Zhang, X. Xu, Inorganic Chem. Commun. 2012, 16, 37. (b) X. Shang, J. Yuan, Z. Du, Y. Wang, S. Jia, J. Han, Y. Li, J. Zhang, X. Xu, Helv. Chim. Acta 2013, 96, 719. (c) O. D. Is, F. B. Koyuncu, S. Koyuncu, E. Ozdemir, Polymer 2010, 51, 1663. (d) F. Zhang, Y.-h. Zhou, X.-p. Bao, Supramol. Chem. 2015.

[14] (a) H. Grampp, M. Maeder, C. J. Meyer, A. D. Zuberbuhler, Talanta 1985, 32, 95. (b) H. Grampp, M. Maeder, C. J. Meyer, A. D. Zuberbuhler, Talanta 1985, 32, 257. (c) H. Grampp, M. Maeder, C. J. Meyer, A. D. Zuberbuhler, Talanta 1985, 32, 1133.

[15] M. J. Frisch, G. W. Trucks, H. B. Schlegel, G. E. Scuseria, M. A. Robb, J. R. Cheeseman, J. Montgomery, J. A., T. Vreven, K. N. Kudin, J. C. Burant, J. M. Millam, S. S. Iyengar, J. Tomasi, V. Barone, B. Mennucci, M. Cossi, G. Scalmani, N. Rega, G. A. Petersson, H. Nakatsuji, M. Hada, M. Ehara, K. Toyota, R. Fukuda, J. Hasegawa, M. Ishida, T. Nakajima, Y. Honda, O. Kitao, H. Nakai, M. Klene, X. Li, J. E. Knox, H. P. Hratchian, J. B. Cross, C. Adamo, J. Jaramillo, R. Gomperts, R. E. Stratmann, O. Yazyev, A. J. Austin, R. Cammi, C. Pomelli, J. W. Ochterski, P. Y. Ayala, K. Morokuma, G. A. Voth, P. Salvador, J. J. Dannenberg, V. G. Zakrzewski, S. Dapprich, A. D. Daniels, M. C. Strain, O. Farkas, D. K. Malick, A. D. Rabuck, K. Raghavachari, J. B. Foresman, J. V. Ortiz, Q. Cui, A. G. Baboul, S. Clifford, J. Cioslowski, B. B. Stefanov, G. Liu, A. Liashenko, P. Piskorz, I. Komaromi, R. L. Martin, D. J. Fox, T. Keith, M. A. AlLaham, C. Y. Peng, A. Nanayakkara, M. Challacombe, P. M. W. Gill, B. Johnson, W. Chen, M. W. Wong, C. Gonzalez, J. A. Pople, Gaussian 03, Revision D.02, Gaussian, Inc., Wallingford CT, 2004.

[16] (a) J. J. P. Stewart, J. Comp. Chem. 1989, 10, 209. (b) J. J. P. Stewart, J. Comput. Chem. 1989, 10, 221.

[17] (a) A. D. Becke, J. Chem. Phys. 1993, 98, 5648. (b) C. Lee, W. Yang, R. G. Parr, Phys. Rev. B 1988, 37, 785. 